\title{
Municipal Solid Waste as Sustainable Energy Source for Brazil
}

\author{
Fátima Aparecida de Morais Lino*, Kamal Abdel Radi Ismail \\ Energy Department, Faculty of Mechanical Engineering, State University of Campinas, Barão Geraldo, Campinas, Brazil
}

Email address:

fatimalino@fem.unicamp.br (F. A. M. Lino),kamal@fem.unicamp.br (K. A. R. Ismail)

\section{To cite this article:}

Fátima Aparecida de Morais Lino, Kamal Abdel Radi Ismail. Municipal Solid Waste as Sustainable Energy Source for Brazil. International Journal of Energy and Power Engineering. Vol. 4, No. 4, 2015, pp. 197-204. doi: 10.11648/j.ijepe.20150404.12

\begin{abstract}
Depositing municipal solid waste (MSW) in dumps has provoked serious impacts in Brazil in the last decades because of the gas and liquid effluents which contaminate the soil and underground water resources in addition to emitting greenhouse gases (GHG) to the atmosphere. To mitigate these impacts, this paper presents proposals for treatment of solid waste by recycling, incineration and biodigestion with the objective of showing the decision makers that solid waste is not a problem and can be a solution as a source of renewable energy. The results of the study show that the MSW proposed treatments represent a forward march for sustainability and environment preservation. The biological treatment option can produce about 221.7 $\mathrm{GWh} /$ month or energy enough for 1.26 million homes. The incineration treatment option can produce energy of about 2902.6 $\mathrm{GWh} / \mathrm{month}$. The generated ash of about $10 \%$ can be used for manufacturing bricks, biofuels and other products. In addition, in all processes $\mathrm{CO}_{2}$ emissions are significantly reduced.
\end{abstract}

Keywords: Municipal Solid Waste, Sustainability, Energy, Recycling, Incineration, Biodigestion

\section{Introduction}

Collection and treatment of municipal solid waste (MSW) is one of the essential sanitary services for the society. Due to the world demographic explosion during the last 70 years, this service was realized partially in many countries [1]. In Brazil, which is the fifth most populated country in the world, the situation is not different. Collecting and treating the solid waste generated by about 202 million inhabitants [2] is a real challenge for public administration. The country population increases at the rate of about $1.17 \%$ and the urban population amounts to $84.9 \%$ [3].

The amount of 259,547 t/day of MSW collected in 2008, was generated by $98 \%$ of the population and was deposited in 2906 open dumps, 1310 covered dumps and 1254 sanitary landfills [4]. The first two methods of disposal of MSW are inadequate because of soil and underground water contamination, and emission of GHG (greenhouse gas) to the environment. Some countries in Europe and Japan treat MSW including energy production and other applications to reduce its offensive impacts and their dependence on landfills $[5,6,7$, $1]$.

MSW is composed of organic degradable matter such as food leftovers, paper, cardboard, and pruning of plants; organic matter non degradable such as plastics and inorganic matter such as glass and metals which takes hundreds of years to decompose.

In general, solid waste has energy and economic potential. It can be used as a renewable source of energy when incinerated producing heat or biodegraded producing biogas. Also part of it can be recycled resulting in financial gain, energy and raw material savings, in addition to the reduction of $\mathrm{CO}_{2}$ emissions. Additional benefits can be obtained such as reducing public expenditure for treating the solid waste, creating jobs, enhancing the social inclusion of poor families and increasing the life useful of landfills [8, 9, 4, 10, 11]. Actually Brazil recycles less than $2 \%$ of the collected MSW and hence most of the inherent potential of MSW is wasted.

As an attempt to improve the actual situation of waste treatment in the country and reduce its environment and public health negative impacts, the Federal Government launched in 2010 the Solid Waste National Policy (PNRS) law number 12.305. Among the actions established by this law are the increase of the recycled mass to $20 \%$ until 2015 and the extinction of dumps in august 2014, what hasn't happened yet [12]. 


\section{Literature Review: Treatment of MSW}

Developed countries as Netherland, Germany, Sweden, Switzerland and Japan have given high priorities in their public policies to incineration and biodigestion of MSW with or without energy recovery and incentives to recycling with the result that a big part of generated MSW is deviated from landfills. Data from Unstat [5] and OECD [6] show that deposition of MSW in landfills in 2009 in Germany was $0.4 \%$ and in Netherland was $0.7 \%$. Switzerland treats nearly $100 \%$ of MSW generated by the population.

\subsection{Recycling}

Recycling is a way to reuse the solid waste and benefit from its inherent financial and energy potential. This involves a number of processes such as separation of the recyclables in residences, selective collection, sorting by type of material, pressing, packaging and selling to recycling industry $[8,9,10,11]$.

Many reports on recycling programs and experiences of different countries are available in the literature as Read [13] and Defra [14] in the UK; Themelis et al. [15] and EPA [16] in the USA; Okuda et al. [17] and Ministry of the Environment [18] in Japan; Pariatamby and Tanaka [19] in China; Lino and Ismail [11]; Lino et al. [9] and Lino [8] in Brazil.

In Brazil, the selective collection started in 1980, and after 30 years, only 994 of the 5,564 Brazilian municipalities implemented recycling programs with the result that MSW selectively collected is about $1.2 \%$ [4]. The selective collection is implemented in capitals and big urban centers, mainly in the South and Southeast regions where this service is essentially realized by the public sector, organized cooperatives and associations [8].

\subsection{Landfilling}

The deposition of organic waste in landfill generates biogas which is essentially a mix of carbon dioxide $\left(\mathrm{CO}_{2}\right)$ and methane $\left(\mathrm{CH}_{4}\right)$. The use of biogas for electricity generation is a common practice in many countries. Germany had, for example, in 2008, about 4,100 biogas plants supplying approximately 1,435 megawatts of electric energy [20]. In the United States in 2011, landfill methane capture installations produced 14.3 TWh of electricity, enough to provide power to more than 1 million homes [21]. The number of installations for the commercial utilization of biogas increased in developing countries especially in China, India and Nepal where the biogas from waste treatment has been used as energy source [22].

In Brazil, experimental studies are realized to show the potential of energy generation from landfill biogas as the pilot plant from landfill in Muribeca, Recife (PE), producing about $80 \mathrm{~m}^{3} / \mathrm{h}$ of biogas, but with potential about $100 \mathrm{~kW}$ [23]. In the state of São Paulo, three thermoelectric power plants are installed in landfills sites producing about $75 \mathrm{MW}$ while other installations in different localities are producing about $109 \mathrm{MW}$ [24]. The rate of energy production from
MSW varies between 0.66 to $1.45 \mathrm{MWh} / \mathrm{t}$ [24].

MSW landfilling is a common practice in many countries. One of the major problems associated with it is the fugitive biogas which escapes through cracks and voids in the covering layer and sidewalls and released freely to the atmosphere. Monni et al. [25] considered that the rate of fugitive biogas flow varies between 25 to $50 \%$ depending on the construction conditions of the landfill. An alternative way to treat solid waste, improve the public cleaning service, and at the same time produce energy is through incineration, considering that the flue gases will be monitored and carefully treated before its release to the ambient.

\subsection{Incineration of MSW}

The first incineration plant for treating MSW was developed and operated in Manchester (UK) in 1876, and since then incineration is considered as an effective tool to treat dangerous and infectious material from hospitals and similar establishments. This process reduces the original volume of the material to about $10 \%$ and can be a viable option for municipalities where there are no suitable and cheap areas for constructing well engineered landfills (sanitary landfills).

Incineration is extensively used in Japan [26], Europe [27], and Korea [28]. The utilization of thermal energy from incineration for heating and generation of electricity is a viable option accepted by the public opinion due to the evolution of pollution control equipments, instrumentation, and the development of highly efficient systems for treating effluents [29]. In Brazil, incineration is only used for treatment hospitals wastes [30]. In modern incineration units one ton of MSW can produce up to $600 \mathrm{kWh}$ [31]. This amount of energy is sufficient for four average Brazilian residences [32].

Considering the huge amounts of MSW generated daily, the energy, financial losses and the negative ambient and public health impacts, this paper presents assessment of proposals for MSW treatments based upon recycling, biodigestion and incineration showing the energy, economic and ambient potential of MSW.

\section{Materials and Methods}

\subsection{Materials}

From the literature review, it is clear that recycling part of MSW together with landfilling and incineration including energy recovery are possible treatment routes to ensure environmental sustainability, additional energy and financial gains.

In this way, this paper presents an assessment of two possible routes for the treatment of MSW: biogestion and incineration and both with $10 \%$ of reuse of recyclables generated in the country, as show Figs. 1 and 2. Recognizing that there are different consuming habits in Brazil, an average MSW composition based upon [33] is used since there is no other official data available after the above date. 
The data used is only for MSW generated in urban areas. Since the main objective is assessing the relative merits and drawbacks of each proposal, the sensitivity of the results due to the uncertainty of the data will affect equally the results from both routes. Were also used global values obtained from reports for the production and composition of biogas from landfills, emission rates and fuel consumption aid in incineration. Again, the uncertainty in these global values may affect the results.

The parameters and data used in the calculations are presented in Table 1 while Table 2 presents the composition of solid waste in Brazil.

Table 1. Data used in the calculations.

\begin{tabular}{llll}
\hline Description & Reference value & Adopted value & Reference \\
\hline Biogas production from landfill $(\mathrm{L} / \mathrm{kg})$ & $35-45$ & 40 & {$[34]$} \\
Specific mass of $\mathrm{CO} 2\left(\mathrm{~kg} / \mathrm{m}^{3}\right)$ & & 1.83 & {$[35]$} \\
Emission of $\mathrm{MSW}$ incinerated $\left(\mathrm{tCO}_{2} / \mathrm{TJ}\right)$ & $10-40$ & 25 & {$[25]$} \\
$\mathrm{LCV}$ of $\mathrm{CH} 4\left(\mathrm{MJ} / \mathrm{m}^{3}\right)^{1}$ & & 33.95 & {$[35]$} \\
Avoided emissions in recycling $\left(\mathrm{CO}_{2} / \mathrm{t}\right)$ & & 1.971 & {$[11]$} \\
Avoided energy in recycling $(\mathrm{GJ} / \mathrm{t})$ & & 31.629 & {$[11]$} \\
$\mathrm{LCV}$ of MSW incinerated $(\mathrm{kJ} / \mathrm{kg})$ & $5250-10,264$ & 6,130 & {$[31]$} \\
Auxiliary fuel for incineration $\mathrm{LPG}(\mathrm{kg} / \mathrm{t})^{2}$ & & 8.0 & {$[36]$} \\
Efficiency of recovered biogas $(\%)$ & $50-75$ & 75 & {$[25]$} \\
Emissions due to combustion of $\mathrm{LPG}(\mathrm{kg} \mathrm{CO} / \mathrm{kg})$ & & 3.019 & {$[36]$} \\
$\mathrm{LCV}$ of commercial $\mathrm{LPG}(\mathrm{MJ} / \mathrm{kg})$ & $40.05-46.05$ & 40.05 & {$[35]$} \\
\hline
\end{tabular}

(1) Lower calorific value; (2) Liquefied Petroleum Gas.

Source: Prepared by the authors.

Table 2. Typical composition of solid waste in Brazil.

\begin{tabular}{lllllll}
\hline Material & Organic Matter (\%) & Paper/cardboard (\%) & Plastics (\%) & Glass (\%) & Metal (\%) & Others (\%) \\
\hline 52.5 & 24.5 & 2.9 & 1.6 & 2.3 & 16.2 \\
\hline
\end{tabular}

Source: [33]

\subsection{Methods}

This Section Presents the Simplified Diagrams of the Proposals, Explanations and Equations used in the Calculations

\subsubsection{Landfilling of MSW with Biogas Utilization}

Fig. 1 shows a simplified representation for the biological treatment of MSW. The amount of recyclables separated and collected selectively for reuse is $10 \%$. Organic matter and the rest of uncollected recyclables are transported to landfills equipped for biogas collection and utilization for heat and electricity production. The biodigestion of the organic matter in MSW can reduce its volume by about 20 to $25 \%$ [36].

From the gravimetric analysis of MSW, (Table 2) it is possible to determine the amount of recyclables from equation 1

Quantity of recyclables $=$ Recyclables fraction $\mathrm{x}$ Collected MSW

The financial gain from commercializing the recyclables is obtained from equation 2 .

Financial gain $=$ Price of recyclables U\$ / ton $\mathrm{x}$ quantity of recyclables

Recycling eliminates the necessity of energy to process raw material e consequently the associated emissions. Lino and Ismail [11], by using the data from [37, 38, 39] together with the recyclables composition, calculated the energy savings per ton of recyclable mix (Table 1). The same procedure is used to calculate the amount of avoided $\mathrm{CO}_{2}$ due the reuse of the recyclables (Table 1).

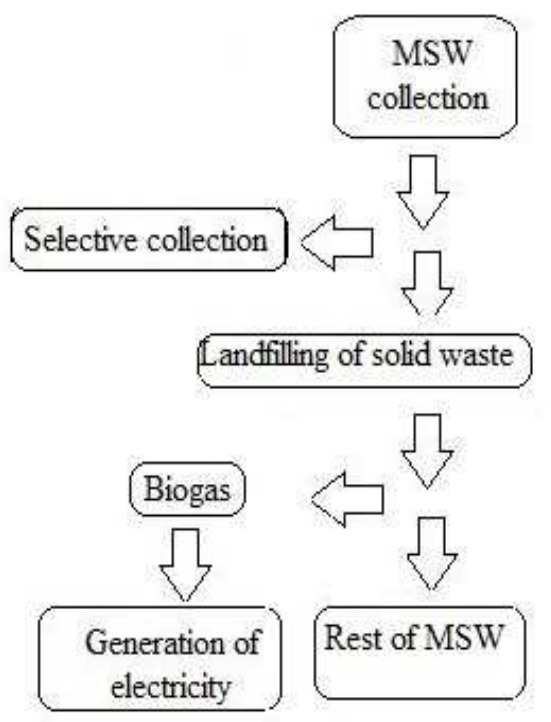

Fig. 1. Recycling and biological treatment of MSW. 
The avoided energy and emissions due to recycling can be calculated form equations 3 and 4 [11],

$$
\begin{gathered}
\text { Avoided energy }=\text { Avoided energy factor } x \text { Recyclable } \\
\text { mass }
\end{gathered}
$$

Avoided emissions $=$ Avoided emissions factor $\mathrm{x}$ Recyclable mass

The rest of MSW is transported to landfill. The rate of biogas production depends on MSW composition, ambient conditions, humidity and the average $\mathrm{pH}$ value. The average quantity of biogas production [34] can be calculated from equation 5 as

Quantity of generated biogas $=$ Rate of biogas production $\mathrm{x}$ biodegradable mass in MSW

The generated biogas is collected, cleaned and the forwarded for utilization or for energy generation. Not all the biogas generated is collected, some of it escapes and the recovery efficiency may vary and, in the present work the value of $75 \%$ was used [25]. The collected gas can be calculated from equation 6

Collected biogas $=$ Recuperation efficiency $\mathrm{x}$ volume of generated biogas

The generated biogas is principally composed of $\left(\mathrm{CH}_{4}\right)$ and $\left(\mathrm{CO}_{2}\right)$ and small quantities of other gases. In the present study a composition of biogas of $45 \% \mathrm{CH}_{4}$ and $55 \% \mathrm{CO}_{2}$ is adopted. The energy contained in the collected biogas can be calculated by using the lower calorific value (LCV) of the methane [35] or by using an average value for the biogas LCV. Equation 7 can be used to calculate the energy content of the collected biogas.

Energy content of the collected biogas = mass of collected biogas $\mathrm{x}$ LCV of the biogas

\subsubsection{Calculation of Emissions}

The combustion of $\mathrm{CH}_{4}$ produces the same quantity of $\mathrm{CO}_{2}$ according to equation 8

$$
\mathrm{CH} 4+2 \mathrm{O} 2=\mathrm{CO} 2+2 \mathrm{H} 2 \mathrm{O})
$$

Hence the quantity of $\mathrm{CO}_{2}$ generated due to the combustion of collected biogas is equal to quantity of collected biogas or

$\mathrm{CO} 2$ generated from the combustion of collected biogas $=$ quantity of collected biogas

The calculations of the fugitive biogas [25] and the equivalent emissions $\left(\mathrm{CO}_{2} \mathrm{e}\right)$ can be calculated from equations 10 and 11

Quantity of fugitive biogas $=(1-\eta) \times$ Quantity of generated biogas

Equivalent $\mathrm{CO} 2 \mathrm{e}$ of $\mathrm{CH} 4=\mathrm{GWP}$ x CH4 quantity

where $\eta$ is the biogas recovery efficiency and equals $75 \%$, and GWP $=25$ is the GWP of methane.

\subsubsection{Incineration of MSW}

Fig. 2 shows a simplified flow chart of the thermal process for treating MSW. Subtracting $10 \%$ of the recyclables, the rest of MSW is directed to the mass incineration plant where it is burnt with the help of auxiliary fuel, considered here as LPG. Energy generated from the combustion of MSW can be used to generate steam and electricity. The heat content of the hot flue gases can be recovered and used for heating admission air, feed water for the boilers and other applications. After the cleaning processes, the gases are discharged into the ambient. The remains of the incineration process can be recycled or used in road paving and civil construction etc.

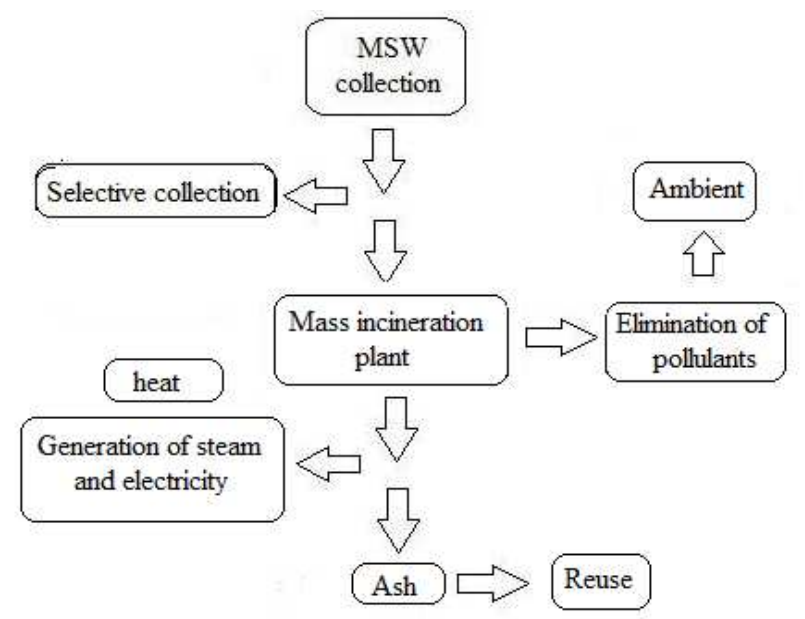

Fig. 2. Recycling and incineration of MSW.

As in the previous case, financial, ambient and energy gains by recycling can be calculates from equations 1 to 4 . The mass of MSW sent for incineration is the mass of collected MSW minus the mass of commercialized recyclables $(10 \%)$. The heat released during incineration depends upon the heat content of MSW and can be calculated from equation 12

Heat released during incineration $=$ Mass of MSW incinerated $\mathrm{x}$ Heat content of MSW

To start incineration and maintain the temperature level in the furnace, LPG is used in the present work. Equation 13 can be used to determine the amount of heat released by the auxiliary fuel.

Energy released by the auxiliary fuel = mass of the auxiliary fuel $x$ LCV of the auxiliary fuel

The net heat released from the incineration process is the difference between the heat released by incineration of MSW and the heat released due to the combustion of the auxiliary fuel as in equation 14

Net heat released in the incineration process $=$ Heat of combustion of MSW - Heat the auxiliary fuel

This energy will be converted to electricity with an average 
conversion efficiency of about $30 \%$.

The amount of $\mathrm{CO}_{2}$ generated due to the combustion of both MSW and the auxiliary fuel can be calculated by using data (Table 1) and equations 15 and 16.

Quantity of CO2 generated due to the combustion of LPG $=$ Emission factor $\mathrm{x}$ mass of LPG

Quantity of CO2 generated due to the combustion of MSW = Emission factor $\mathrm{x}$ mass of MSW

\section{Results}

In this section, the actual situation and the results from the proposals are calculated, presented and analyzed.

\subsection{Evaluation of MSW Actual Treatment}

The collected MSW [4] is 259,547 t/ day and from Table 2 the organic matter in MSW is $52.5 \%$ and paper and cardboard is $24.5 \%$. The total amount of biodigestable matter is $77 \%$ or $199,851.2 \mathrm{t}$ /day. The selective collection of recyclables [4] is 3,122 t/day and the quantity of paper and cardboard in the selective collection is $24.5 \%$ or $765 \mathrm{t} /$ day. Hence the amount of biodegradable matter for landfilling is $199,851.2-765=199,086.2 \mathrm{t} /$ day.

The rate of biogas production (Table1), varies according to its composition, ambient conditions, and humidity. Due to the actual conditions of landfills a biogas production rate average value of $0.030 \mathrm{~m}^{3} / \mathrm{kg}$ is used, the amount of generated biogas is $5.972586 \times 10^{6} \mathrm{~m}^{3} /$ day $=2.1799939 \times 10^{9}$ $\mathrm{m}^{3} /$ year. Considering the composition of biogas as $45 \% \mathrm{CH}_{4}$ and $55 \% \mathrm{CO}_{2}$, it is possible to calculate the total amount of $\mathrm{CO}_{2} \mathrm{e}$ as $25.72 \times 10^{9} \mathrm{~m}^{3} /$ year or $47.1 \mathrm{Mt} \mathrm{CO}_{2} /$ year.

The amount of recyclables collected [4] is $3122 \mathrm{t} /$ day and the selling price of a ton of recyclables mix is $\mathrm{R} \$ 450$ (US\$ 203,71). Hence the financial gain is $1,404,900 \mathrm{R} \$$ /day (US\$ 635,982.62) or R\$ 42,147,000 /month (US\$ 19,079,479).

The calculations show that the energy savings amounts to 98745.7GJ/day $=10011.72 \mathrm{GWh} /$ year while the avoided emissions comes to $6153.5 \mathrm{tCO}_{2} /$ day $=2.24 \mathrm{MtCO}_{2} /$ year. Summary of the calculations is presented in Table 3 .

\subsection{Proposals for Treatment of MSW}

The models used for the evaluation of the proposed treatment routes are presented with the respective equations in section 3.2. Following the procedures outlined in sections 3.2.1, 3.2.2 and 3.2.3 it is possible to obtain the results shown in Table 3 for the proposed treatment routes

\section{Discussion}

\subsection{Actual Situation of MSW Treatment in Brazil}

Analysis of the results shows that the actual situation of
MSW treatment is critical and challenging considering the serious risks to public health and to ambient in addition to the huge economic and energy losses. The MSW actual treatment schemes are not adequate or sufficient to cope with the needs of the population. The national panorama demonstrates that MSW generated by 200 million inhabitants is essentially dumped provoking disastrous consequences to ambient and the population.

Recycling can be considered as an additional instrument for creating jobs, income and conservation and better use of natural resources. Irrespective of the extensive official efforts to encourage the recycling industry these activities are still incipient, about $1.2 \%$.

\subsection{Proposal of MSW Treatment in Brazil}

Benefits due to recycling include economy of energy, water and raw materials, reduction of emissions, reduction of MSW destined to landfills and can be considered as a source of jobs and income for poor families [40]. In the present study an initial target of recycling $10 \%$ is proposed, (observe that the national solid waste policy adopts a target of $20 \%$ ). The proposed target value is considered acceptable since it can be achieved within reasonable period of time by adopting adequate measures such as priorities in public policies and implementation of public awareness programs in a way similar to what was done in UK [13].

Recycling $10 \%$ of the available potential of recyclable, according to Table 3, corresponds to about $8000 \mathrm{t} /$ day and when commercialized can render a sum of US\$ 50 million per month which corresponds to 151,480 minimum national salary (R\$ 724 or US\$ 327.75). Part of these funds can be used to promote selective collection and upgrade infrastructure for MSW treatment. The avoided energy and emissions come to about 256,948.3 GJ/day and 5.84 $\mathrm{MtCO}_{2}$ /year, respectively.

Using the same methodology of calculation, a comparison between recycling in 2008 and this proposal, that is 1.2 and $10 \%$, respectively, shows that the energy, financial gains and the avoided emissions obtained from the sale of recyclables are found to be 2.6 times that of 2008 .

\subsubsection{Landfilling of MSW}

In the proposal of landfilling nearly199 thousand tons of MSW, according to Table 3, can generate about 7 million cubic meters of biogas, which after subtracting the fugitive biogas, can be converted to about 221 million $\mathrm{kWh}$ per month sufficient for the consumption of 1.26 million residences. Considering the electricity tariff of $\mathrm{R} \$ 0.389$ $\mathrm{kWh}$ or US\$ 0.176 per $\mathrm{kWh}$ in the municipality of Campinas (SP) in 2014, the cost of energy generated yearly is nearly equal to the value of three mass incineration plants.

The remaining heat contained in the combustion products can be used for preheating combustion air, feed water for boilers and other applications. 
Table 3. Summary of the results of the proposed treatment routes for MSW.

\begin{tabular}{|c|c|c|}
\hline Description & Situation in 2008 & Proposed MSW treatment \\
\hline \multicolumn{3}{|l|}{ Recycling } \\
\hline Collected MSW (t/day) & 259,547 & 259,547 \\
\hline Available recyclables (t/day) & $81,238.2$ & $81,238.2$ \\
\hline $10 \%$ of available recyclables ( $t /$ day) & - & $8,123.82$ \\
\hline Recyclable collected in 2008 (t/day) & 3,122 & - $\quad$ \\
\hline Monthly gain from the recyclables (R\$ or US\$)* & $42,147,000(19079,675)$ & $109,671,585$ or $(49647,617)$ \\
\hline Avoided energy due to recycling (GJ/day) & $98,745.7$ & $256,948.3$ \\
\hline Emissions avoided by recycling (MtCO2 /year) & 2.24 & 5.84 \\
\hline Treatments for MSW & & $\begin{array}{l}\text { Landfilling with } \\
\text { biogas recovering }\end{array}$ \\
\hline Organic matter for landfilling ( $t /$ day) & $199,086.2$ & $193,492.3$ \\
\hline Waste for incineration ( $t /$ day) & & $199.851,2$ \\
\hline Biogas generated (m3/dia) & $5.9726 \times 106$ & $7.73969 \times 106$ \\
\hline Recovered biogas (m3/day) & & $5.80477 \times 106$ \\
\hline Energy generated by the biogas ( $\mathrm{J} /$ day $)$ & & $88.68 \times 1012$ \\
\hline Energy due to incineration ( $\mathrm{J} /$ day $)$ & & $1225.0879 \times 012$ \\
\hline Energy due to incineration ( $\mathrm{J} /$ month) & & $36752.64 \times 1012$ \\
\hline Net energy due to incineration (Je /month) & & $10449.4999 \times 1012$ \\
\hline Energy due to biogas (Je /month) & & $798.097 \times 1012$ \\
\hline Energy due to biogas (GWh /month) & & 221.694 \\
\hline Energy due to incineration (GWh/month) & & 2902.639 \\
\hline Number of homes attended by generated energy** & & $16,476,663$ \\
\hline $\mathrm{CO} 2$ emissions (Mt CO2 /year) & 47.0748 & 12.941 \\
\hline Fugitive biogas (m3/day) & & $1.93492 \times 106$ \\
\hline Equivalent emissions due to fugitive biogas ( $\mathrm{m} 3 \mathrm{CO} 2 \mathrm{e} /$ day) & & $22.8321 \times 106$ \\
\hline Mass of fugitive biogas (MtCO2e /year) & & 15.251 \\
\hline
\end{tabular}

* Conversion rate to Dollar $=$ US $\$ 2.209 ; * *$ National average residential electric energy consumption $=0.6342 \mathrm{G} \mathrm{Jel} / \mathrm{month}$.

Source: Elaborated by authors.

In this proposal, emissions due to the combustion of biogas are about $3.88 \mathrm{Mt} \mathrm{CO}_{2}$ /year in addition to the quantity of 15.25 $\mathrm{MtCO}_{2} \mathrm{e} /$ year due to fugitive biogas. This sum is 2.5 times lower than the 2008 emissions data.

\subsubsection{Incineration}

Incineration of $200,000 \mathrm{t} /$ day of MSW can produce a net thermal energy of 37,000 $\mathrm{TJ} /$ month or $10,000 \mathrm{TJ}_{\mathrm{el}} /$ month. This amount of energy is sufficient for the consumption of 16.5 million residences each consuming an average of 0.6342 $\mathrm{GJ}_{\mathrm{el}} /$ month. Emissions due to incineration of MSW are of the order of $12.94 \mathrm{Mt} \mathrm{CO}_{2} /$ year compared to nearly $19 \mathrm{MtCO}_{2} \mathrm{e} /$ year in the case of landfilling.

From these results it is possible to conclude that the energy and environment benefits from incineration are much more than those of landfilling. The thermal treatment leaves about $10 \%$ of ash which can be reused. This can be a solution for many cities as Campinas (SP) where there is no available land to construct landfills. It is important to mention that incineration is a viable option but must have adequate installations equipped with equipments for monitoring, control and treatment of effluents to ensure safe and adequate operation [40].

\section{Conclusions}

The results show that either of the proposals can produce favorable impacts such as reduction of emissions, reduction of contamination of soil and water resources, more energy generation, saving raw materials and water resources.
The proposal of landfilling MSW with biogas capture can generate energy enough for about $1.8 \%$ of the total 65 million of Brazilian residences and emit to the atmosphere about 15.25 $\mathrm{MtCO}_{2} \mathrm{e} /$ year.

One inconvenient aspect is the fugitive gas (biogas) which escapes at the site and released freely to ambient aggravating the greenhouse effects. There is always a risk of leachate leakage which could contaminate the soil and underground water sources. Even after closing the landfill site the remaining biodegradable matter continue producing biogas at smaller rates which needs to be continually monitored for many years to avoid risks of explosion.

Incineration, on the other hand reduces MSW mass to about $10 \%$ of ash which can be reused. The capital costs for an incinerator will depend on the quality of waste to be processed and the technology employed. Costs will not only comprise those associated with the purchase of the incinerator plant, but also costs for land procurement and preparation prior to building and also indirect costs, such as planning, permitting, contractual support and technical and financial services over the development cycle. Facilities in operation after 2000 report a cost of $£ 82$ per tonne ( $£ 44-£ 101$ range) [41].

Based on this assessment, the authors consider that incineration is the a most viable system for treating MSW in Brazil, because it reduces the mass of solid waste dumped in soil, avoids problems as contamination of soil, air, and underground water and finally avoids risks to public health. In addition, one should forget that landfill needs of continuous monitoring for many years after its deactivation. 


\section{Acknowledgements}

The authors wish to thank the CNPQ for the Doctorate scholarship to the first author and the PQ Research Grant to the second author.

\section{References}

[1] World Bank, Urban Development Serie. What a waste: A global review of solid waste management, Hoornweg, D. and Bhada-Tata (authors), World Bank, 15p. USA, 2012.

[2] IBGE - Instituto Brasileiro de Geografia e Estatística, Projeção população brasileira: abril de 2014. Available at: http://www.ibge.gov.br/home/

[3] IBGE - Instituto Brasileiro de Geografia e Estatística, Banco de dados Brasil: população, 2012. Available at: http://www.ibge.gov.br/paisesat/main_frameset.php.

[4] IBGE - Instituto Brasileiro de Geografia e Estatística, Pesquisa Nacional de Saneamento Básico 2008. BR, 2010, Available at: http://www.ibge.gov.br/home/estatistica/populacao/condicaod evida/pnsb2008/PNSB_2008.pdf.

[5] UNSTAT -United Nation Statistic Division, Environmental indicators, Waste: Municipal waste treatment 2011. Available at:

https://unstats.un.org/unsd/environment/wastetreatment.htm

[6] OECD - Organization for Economic Co-operation and Development Environmental Outlook to 2050, The consequences of inaction 2012, OECD Publishing. Available at: http://dx.doi.org/10.1787/9789264122246-en.

[7] OECD - Organization for Economic Co-operation and Development, Total amount generated of municipal waste, in Factbook Country Statistical profiles 2013 edition/Environmental, OECD. StatExtracts. Available at: http://stats.oecd.org/Index.aspx?DatasetCode $=$ CSP2013.

[8] FAM Lino, Consumo de energia no transporte da coleta seletiva de resíduo sólido domiciliar no município de Campinas (SP), Master Thesis, Universidade Estadual de Campinas: Unicamp. Brasil, 2009.

[9] FAM Lino, WA Bizzo, EP Silva, KAR Ismail, Energy impact waste recyclable in a Brazilian Metropolitan, Resources, Conservation and Recycling, vol. 54, pp. 916-922, 2010.

[10] FAM Lino, KAR Ismail, Energy and environmental potential of solid waste in Brazil. Energy Policy, vol. 39, pp. 3496-3502, 2011.

[11] FAM Lino, KAR Ismail, Analysis of the potential solid waste in Brazil. Environmental Development, Vol.4, 2012 pp. 105-113, 2012.

[12] Brasil/ MMA - Ministério do Meio Ambiente, Política Nacional de Resíduo Sólido, 2014, Available at: http://www.mma.gov.br/cidades-sustentaveis/residuos-solidos/ politica-nacional-de-residuos-solidos

[13] AD Read, A weekly doorstep recycling collection, I had no idea we could, Resources, Conservation and Recycling, vol. 26, pp. 217-249, 1999.

[14] DEFRA - Department for Environment Food and Rural Affairs, National Statistic. Statistics on waste managed by local authorities in England in 2012/13. 2013a, Available at: https://www.gov.uk/government/uploads/system/uploads/attac hment_data/file/255610/Statistics_Notice1.pdf.

[15] NJ Themelis, CE Todd, 'Recycling in a megacity', Journal of the Air \& Waste Management Association, vol. 54, pp. 389-395, 2004.

[16] EPA- Environmental Protection Agency, Municipal Solid Waste Generation, Recycling, and Disposal in the United States: Facts and Figures for 2012, 2014. US EPA. Available at: http://www.epa.gov/waste/nonhaz/municipal/pubs/2012_msw fs.pdf

[17] I Okuda, VE Thomson, 'Regionalization of municipal solid waste management in Japan: Balancing the proximity principle with economic efficiency, Environment Management, vol. 40, pp. 12-19, 2007.

[18] Ministry of the Environment, Solid Waste Management and Recycling Technology of Japan: Toward a Sustainable Society, 2012. Available from: http://www.env.go.jp/recycle/circul/venous_industry/en/broch ure.pdf.

[19] A Pariatamby, M Tanaka, Municipal Solid Waste Management in Asia and the Pacific Islands: Challenges and Strategic Solutions, Springer Singapore Heidelberg New York Dordrecht London, 2014.

[20] P Taglia, Biogas: Rethinking the Midwest's Potential. Clean Wisconsin, 2010. Available at: $\mathrm{http} / / /$ issuu.com/cleanwi/docs/biogas.

[21] REN21 - Renewable Energy Policy, Network for the 21st Century, Global Status Report, Paris: 2012. Available at: http://www.martinot.info/REN21_GSR2012.pdf.

[22] REN21 - Renewable Energy Policy: Network for the 21st Century, Global Status Report, Paris: 2007. Available at: http://www.ren21.net/Portals/0/documents/activities/gsr/RE20 07_Global_Status_Report.pdf

[23] FJ Maciel, JF Jucá, A Codeceira Neto, PB Carvalho Neto, Recuperação de biogás em aterros de resíduos sólidos urbanos - Projeto piloto da Muribeca, V Congresso de Inovação Tecnológica em Energia Elétrica (V CITENEL), Belém-PA: 2009.

[24] MME/Aneel, Atlas de Energia Elétrica do Brasil- Biogás, Ministério de Minas e Energia/Agência Nacional de Energia Elétrica, $3^{\text {a }}$ ed. Brasil, 2008. Available from: $\mathrm{http} / / / \mathrm{www}$.aneel.gov.br/arquivos/PDF/atlas3ed.

[25] S Monni, R Pipatti, A Lehtilä, I Savolainen, S Syri, Global climate change mitigation scenarios for solid waste management, VTT publications 603, ESPOO, 2006.

[26] H Cheng, Y Hu, Municipal solid waste (MSW) as a renewable source of energy: current and future pratices in China, Bioresource Technology, vol. 101, pp. 3816-3824, 2010.

[27] CEWEP- Confederation of European Waste-to-Energy Plants, A decade of Waste-to-Energy in Europe (2001-2010/11); 2013, Available http://www.cewep.eu/information/publicationsandstudies/state ments/ceweppublications/m_1174

[28] JM Park, SB Lee, MJ Kim, OS Kwon, DI Jung, Behavior of PAHS from sewage sludge incinerators in Korea, Waste Management, vol. 29, pp. 690-695, 2009. 
[29] FEA - Federal Environment Agency. Biogas production in Germany: Umweet Bunder Amt. by Graaf, D. and Fenler, R., 2010, Available at: http://www.spin-project.eu/downloads/QBlackground_paper_ biogas_germany_en.pdf.

[30] IBGE - Instituto Brasileiro de Geografia e Estatística. Atlas de saneamento, BR: Rio de Janeiro, 2011.

[31] WR Niessen, Combustion and Incineration Processes, 3rd Edition: Marcel Dekker, Inc. New York, 2002.

[32] Brasil/MME- Ministério de Minas e Energia, Anuário Estatístico de energia elétrica 2013, BR: Rio de Janeiro, Epe 2013, Available at: http://www.epe.gov.br/AnuarioEstatisticodeEnergiaEletrica/20 130909_1.pdf

[33] IPT/Cempre, Lixo municipal: manual de gerenciamento integrado, Instituto de Pesquisa Tecnológica \& Compromisso Empresarial para Reciclagem, BR: São Paulo, 2000.

[34] A Karagiannidis, Waste to Energy: Opportunities and challenges for developing and transition economies, editor Avraam Karagiannidis, London: Springer-Verlag; 2012.

[35] JW Rose, JR Cooper, Technical data on fuels, The British National Committee: 7th edition, London, 1977.
[36] Brasil/MCT- Ministério da Ciência, Tecnologia e Inovação, Projeto Usina Verde - Incineração de resíduos sólidos urbanos, com carga de composição similar ao RDF, evitando emissão de metano e promovendo geração de eletricidade para autoconsumo, BR: Brasília, MCT, 2005. Available at: http://www.mct.gov.br/upd_blob/0018/18123.pdf

[37] F McDougall, P White, M Franke P, Hindle, Integrad solid waste management: a life cycle inventory. Blackwell Science published: $2^{\mathrm{a}}$ ed., USA, 2001.

[38] MP Hekkert., LAJ Joosten, E Worrell, Reduction of CO2 emissions by improved management of material and product use: the case of primary packaging, Resources, Conservation and Recycling, vol. 29, pp. 33-64, 2000a.

[39] MP Hekkert, LAJ Joosten, E Worrell, Reduction of CO2 emissions by improved management of material and product use: the case of transport packaging, Resources, Conservation and Recycling, vol. 30, pp. 1-27, 2000b.

[40] FAM Lino, Proposta de aproveitamento do potencial energético do resíduo sólido urbano e do esgoto doméstico com minimização dos impactos ambientais, Doctorate Thesis, State University of Campinas, BR, 2014.

[41] DEFRA - Department for Environment Food and Rural Affairs. Incineration of municipal solid waste, 2013b. Available at: http://www.defra.gov.uk/publications/ 